\title{
Dissecting Emerging Aspects of Regulatory Circuitry in Man and Mice: Regulatory T Cell Biology
}

\author{
Tania Rahman ${ }^{1,2^{*}}$, Md. Ferdous Seraj ${ }^{3}$, Annelise Casellato ${ }^{4}$ \\ ${ }^{1}$ Department of Biochemistry and Molecular Biology, Bio21 Molecular Science and Biotechnology Institute, University of \\ Melbourne, Melbourne, Australia \\ ${ }^{2}$ Department of Microbiology and Immunology, University of Melbourne at the Peter Doherty Institute for Infection and \\ Immunity, Melbourne, Australia \\ ${ }^{3}$ School of Civil, Environmental and Chemical Engineering, RMIT University, Melbourne, Australia \\ ${ }^{4}$ Departamento de Química Inorgânica, Instituto de Química, Universidade Federal do Rio de Janeiro, Rio de Janeiro, Brazil \\ Email: *tania.rahman@du.ac.bd
}

How to cite this paper: Rahman, T., Seraj, Md.F. and Casellato, A. (2018) Dissecting Emerging Aspects of Regulatory Circuitry in Man and Mice: Regulatory T Cell Biology. Advances in Bioscience and Biotechnology, 9, 443-468.

https://doi.org/10.4236/abb.2018.99031

Received: June 30, 2018

Accepted: August 20, 2018

Published: September 18, 2018

Copyright $\odot 2018$ by authors and Scientific Research Publishing Inc. This work is licensed under the Creative Commons Attribution International License (CC BY 4.0).

http://creativecommons.org/licenses/by/4.0/

\begin{abstract}
Regulatory T cells (Treg), a component of adaptive immunity, are well known for their immunosuppressive roles and their ability to maintain the balance between the immunological and pathological reactions. Treg have been shown to provide protective responses and their depletion has resulted severe pathology in some pathogen infections. The work presented here has unravelled the potential of regulatory cells in the immune system including different repertoir of Treg cell subsets, markers to distinguish them, Treg suppression mechanisms in the pathogenesis of various infections and summarize different mouse models depleting Tregs. These findings would help set up future avenues of research to elucidate a key mechanism of action of these cells and provide new therapeutic insights for pathogenesis and also for broader antibacterial/antiviral/antiproliferative immunity.
\end{abstract}

\section{Keywords}

Regulatory T Cells, Foxp3, tTreg, pTreg, IL-10, TGF- $\beta$, Helios, Neuropilin-1

\section{Introduction}

A hallmark of the immune system is to maintain a harmonious balance and selection among its different components. $\mathrm{B}$ and $\mathrm{T}$ cells are selected rigorously for survival during maturation phase. Among the different repertoire of cell subsets, regulatory $\mathrm{T}$ cells (Treg) have been established as a developmentally and func- 
tionally distinct group that has been recognised as vital for keeping the immune system in check, aiding it to escape from self-targeted pathology and unhindered selection of both $\mathrm{T}$ and $\mathrm{B}$ cell populations [1] [2]. In order to maintain a delicate balance, immune system is required to respond to pathogens, nevertheless is must tolerate beneficial microbes. It is widely acknowledged that Treg play a major role in minimizing deleterious immune mediated pathology caused by harmful microbes and self-antigens and thus making a significant impact to this balance.

\section{Treg}

Treg are currently thoroughly investigated for their key role in the maintenance of balance between the immunological and pathological reactions over the body [3] [4]. They are crucial for the retainment of self-tolerance and the control of immune responses against pathogenic organisms, tumour antigens as well as allergens [5] [6] [7] [8] [9]. Treg are developmentally and functionally different from conventional $\mathrm{T}$ cells. Treg constitute $5 \%$ to $10 \%$ of $\mathrm{CD}^{+} \mathrm{T}$ cells. In the steady state, they are generated in the thymus and can be induced from naïve $\mathrm{CD} 4^{+} \mathrm{T}$ cells in the periphery.

Treg are initially characterized as expressing a $\mathrm{CD} 4^{+} \mathrm{CD} 25^{\text {high }}$ phenotype [10] [11]. However, an increasing number of markers have been identified that express constitutively on Treg. These include: cytotoxic T lymphocyte antigen 4 (CTLA-4), glucocorticoid-induced tumour necrosis factor receptor family related protein (GITR); TNFRSF18 (GITR), CD39, HLA-DR, CD45RA, OX40, $\mathrm{CD} 127^{\mathrm{lo}}$, and $\mathrm{CD} 73$ [12]-[17]. In fact, none of these surface markers are expressed exclusively on Treg. Moreover, as CD25 is expressed on other activated $\mathrm{T}$ cells and there are some Treg in the peripheral tissues which do not express CD25 limiting the use of this marker for Treg [18] [19] [20] [21]. To date the most specific marker identified for the classification of Treg is expression of the transcription factor recognized as forkhead box P3 (Foxp3) [22], which has been exhibited to be expressed specifically in $\mathrm{CD}^{+} \mathrm{T}$ cells. The Foxp3 gene encodes Scurffin, which is identified as a member of forkhead-winged-helix family of transcriptional regulators and is vastly conserved in humans [23]. In mice neither activated $\mathrm{CD}^{+} \mathrm{T}$ cells nor differentiated Th1/Th2 cells express Foxp3 [24] [25]. Foxp3 is found to be expressed almost exclusively by $\mathrm{CD} 4^{+} \mathrm{CD} 25^{+} \mathrm{T}$ cells in both thymus and periphery [26]. Mutation of Foxp3 causes an aggressive $\mathrm{X}$-linked autoimmune disease in scurfy mice [23] and the human equivalent, immune dysregulation, polyendocrinopathy, enteropathy, $\mathrm{X}$-linked syndrome (IPEX) [27] [28]. Moreover, forced expression of Foxp3 can transform naive T cells to Treg [24] [29]. Foxp3-sufficient or Foxp3-deficient mixed bone marrow chimeras study demonstrated that $\mathrm{CD} 4^{+} \mathrm{CD} 25^{+}$cells only developed from Foxp3 sufficient bone marrow suggesting that Foxp3 is indispensible for the development of Treg [24] [30]. Importantly, expression of green fluorescence protein (GFP) under the control of Foxp3 gene showed that Foxp3 expression is limited 
to $\mathrm{CD}^{+} \mathrm{T}$ cells that exhibit suppressive potency [31]. Also, ablation of Foxp3 in Treg results loss of suppressive function and phenotype [32] [33]. Thus, Foxp3 appeared to be a lineage-specification factor of Treg and its expression is indispensable for the development and function of Treg.

\subsection{Functions of Treg}

Preliminary studies with Treg were based on their role in dominant tolerance and development of autoimmune disease. However, a handful of studies indicate that Treg play roles in the development of allergic diseases (reviewed in [34]), in the suppression of anti-tumour immunity [35], during pathogen infection (reviewed in [4]) and in controlling responses to commensal microbes in inflammatory diseases [36]. Treg are well known for their immunosuppressive role of varying immune cells including non-Treg $\mathrm{CD}^{+} \mathrm{T}$ cells [37], $\mathrm{CD} 8^{+} \mathrm{T}$ cells [38], dendritic cells (DC) [39], B cells [40], Th17 cells [41], natural killer (NK) cells [42], macrophages [43] and mast cells [44] which are activated in response to pathogen (Figure 1).

\subsection{Different Subsets of Treg}

Studies of Treg have identified several lineages of cells with different sites of induction, characterization and to a degree with various mechanisms of action. Treg are largely divided in to two major groups: thymus-derived Treg cell

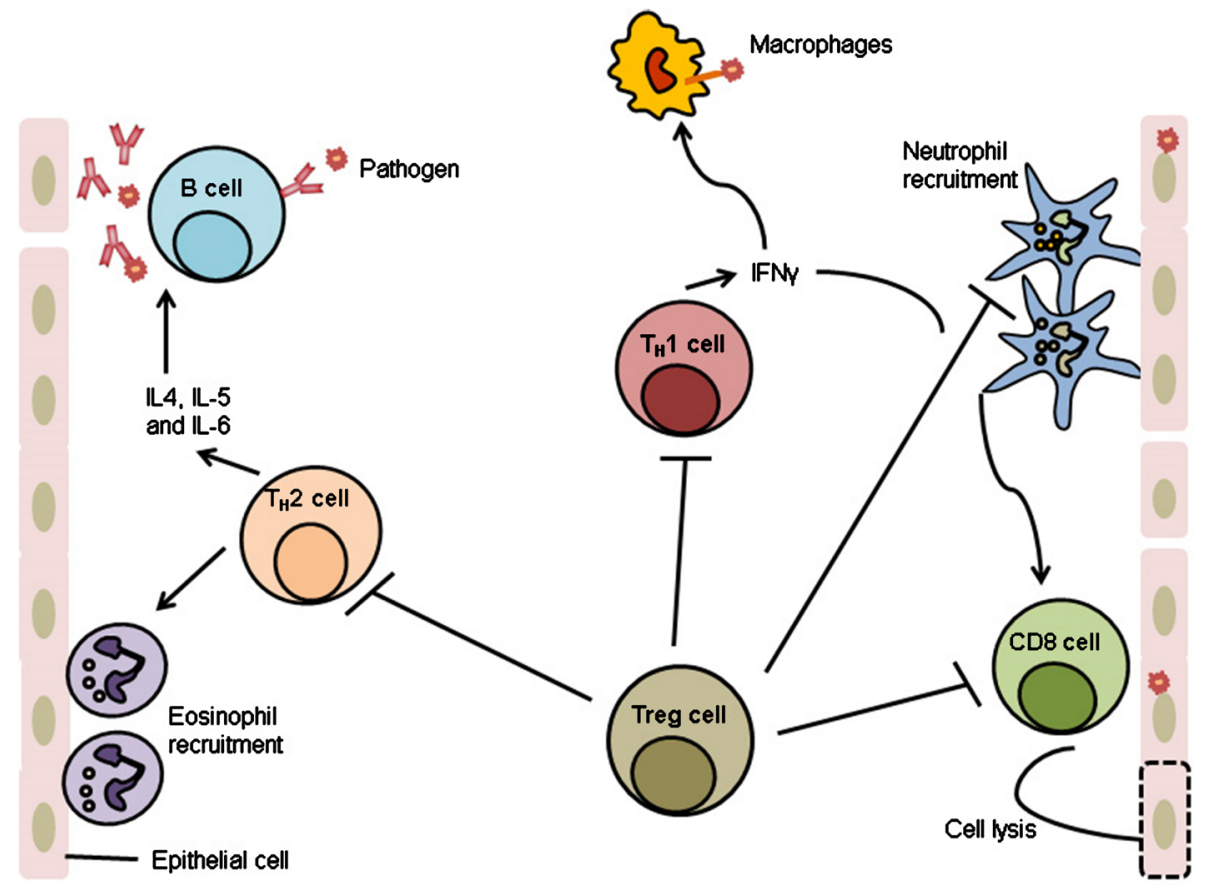

Figure 1. Diverse functions of Treg. Treg control Th1 type cells which though secretion of IFN $\gamma$ activate antimicrobial activity of macrophages and cytotoxic activity of CD8 T cells which lyse host cells infected with pathogen. Treg suppress Th2 type activity which through secretion of IL-4, 5 and 6 activates naïve B cells to produce antibodies as well as controlled recruitment of eosinophils. In addition, Treg alter neutrophil activity by inhibiting their recruitment on the epithelial cell membrane. 
(tTreg) and peripherally derived Treg cell (pTreg) (Table 1) [45] [46] [47] [48].

\subsubsection{Thymus Derived Treg (tTreg)}

Treg that develop within the thymus were often referred to as natural Treg cells as opposed to peripherally derived Treg [46]. tTreg arise during the normal process of $\mathrm{T}$ cell development in the thymus and are imprinted with regulatory function before being released into the periphery. They help prevent autoimmunity and are resistant to thymic deletion and are non-redundantly required for the establishment of self-tolerance [49] [50]. tTreg are known to suppress effector $\mathrm{T}$ cell proliferation in vitro through cytokine independent fashion that is mostly cell contact dependent [51]. The proportion of tTreg appears to be small when any part of this population reacts with antigens [52]. In thymus, tTreg can develop from progenitors to tTreg through tTreg precursor cells [53] [54]. Resting tTreg express CD45RA ${ }^{+}$Foxp $3^{\text {low }}$, while activated tTreg express $C D 45 \mathrm{RO}^{+} \mathrm{Foxp} 3^{\text {high }}$

Table 1. Different subsets of regulatory T cells.

\begin{tabular}{|c|c|c|}
\hline Cell type & Suggested immunosuppressive mechanisms & Ref \\
\hline \multirow{5}{*}{ tTreg/nTreg } & Require CD28 co-stimulation for their development in thymus & {$[58][59][60]$} \\
\hline & STAT5 has been demonstrated to increase the in vivo frequency of tTreg & {$[63]$} \\
\hline & IL-15 is essential for induction of Foxp3 expression in thymocytes & [64] \\
\hline & c-Rel has been shown to be highly expressed by tTreg & {$[65][66]$} \\
\hline & mTECs are responsible for inducing selection of thymic tTreg & {$[2][69]$} \\
\hline \multirow{5}{*}{ pTreg } & TGF- $\beta$ and its receptor signal pathway is essential for the generation of pTreg & {$[82][83][84]$} \\
\hline & $\begin{array}{l}\text { CNS-1, a non-coding region of Foxp } 3 \text { locus are a crucial regulatory element in the } \\
\text { generation of pTreg }\end{array}$ & {$[87][88]$} \\
\hline & Downstream STAT5-dependent signaling is essential for the differentiation of pTreg & {$[92][93][94]$} \\
\hline & RA plays a significant role in enhancing the generation of Foxp3 Treg cells in the GALT & [95] [96] [97] \\
\hline & Smad 2 and Smad 3 participate in the pTreg differentiation process & {$[99][100]$} \\
\hline \multirow{6}{*}{$\operatorname{Tr} 1$} & IL-10 is the major cytokine involved in $\operatorname{Tr} 1$ cells differentiation pathway & {$[102]$} \\
\hline & An essential growth factor for the development of Tr1 is IL-15 & {$[103][104]$} \\
\hline & IL-27 are the major cytokines involved in the differentiation of $\operatorname{Tr} 1$ cells & {$[105][106]$} \\
\hline & c-Maf which activates IL21 facilitates proliferation of Tr1 & {$[105][107]$} \\
\hline & IL21, an autocrine growth factor drives the proliferation of $\operatorname{Tr} 1$ cells & {$[107]$} \\
\hline & AhR induced by IL27 shown to be involved in the differentiation of $\operatorname{Tr} 1$ & {$[108][109]$} \\
\hline \multirow{2}{*}{ Th3 } & Th3 mediate their suppressive activity by the production of TGF- $\beta$. & {$[110]$} \\
\hline & Th3 exhibit a mutual relationship with Th17 cells and exert regulatory potentials & {$[111][112]$} \\
\hline $\operatorname{Tr} 35$ & Tr35 are involved in IL-35 production & {$[113]$} \\
\hline
\end{tabular}


[50] [55]. tTreg constitute about 5\% - 10\% of mouse peripheral CD4 cells which is corresponding to $1 \%-2 \%$ of human counterpart [1].

tTreg develop as a consequence of high-affinity interactions with MHC class II-peptide and their TCR repertoire is primarily self-reactive [56] [57]. They require CD28 co-stimulation for their development in thymus as mice lacking CD28 have an approximately $80 \%$ decrease in the frequency of tTreg [58] [59] [60]. IL-2, a member of $\gamma c$ cytokine family is important for thymic induction of tTreg as mice lacking IL-2R $\beta$ (CD122) develop spontaneous autoimmune diseases which can be blocked by administration of donor Treg [61] [62]. Signal transducer and activator of transcription 5 (STAT5) has been demonstrated to increase the in vivo frequency of tTreg and expression of STAT5 is regulated by IL-2 [63]. IL-15 is also essential for induction of Foxp3 expression in thymocytes [64]. Transcription factor c-Rel, a member of NF- $\kappa B$ family has been shown to be highly expressed by tTreg. c-Rel binds to the conserved non-coding sequence 3 (CNS3) region of Foxp3 locus and in mice deficient in c-Rel, tTreg numbers are markedly reduced [65] [66]. TGF- $\beta$ has been suggested to be absolutely engaged in Foxp3 induction during tTreg development. However, its role has been controversial in tTreg development [67] [68].

Medullary thymic epithelial cells (mTECs) are responsible for inducing selection of thymic tTreg, also bone marrow derived APCs can facilitate tTreg differentiation [2]. Either mTECs or bone derived APCs alone may be sufficient for the generation of $\mathrm{t}$ Treg numbers and both of these subsets can present self-antigens in order to induce development of tTReg [69].

\subsubsection{Peripherally Derived Treg Cell}

pTreg develop extra-thymically when they are exposed to certain regulatory cytokines which are released during inflammatory conditions, upon encountering cognate antigens and costimulation [70] [71]. The antigen-specific Treg repertoire is more abundant than tTreg population and in contrast to tTreg, they migrate towards the sites of inflammation [72]. pTreg play an indispensible role in establishing peripheral tolerance to commensal microbes in gut and non-pathogenic environmental antigens derived from food and they express predominantly in mucosa associated lymphoid tissues (MALT) including peyer's patches and lamina propria of small and large intestines [73] [74]. Moreover, pTreg which present only in the placental mammals are involved in the establishment of maternal-foetal tolerance [75]. Their suppressive actions are mostly cell contact independent and depend on the availability of immunosuppressive cytokines [76] [77]. They are known to develop from CD4 $4^{+}$Foxp $3^{-}$effector $\mathrm{T}$ cells in the periphery and they apparently have a similar TCR repertoire to that of the effector $\mathrm{T}$ cells [78] [79]. In particular, pTreg can convert from $\mathrm{CD} 4^{+} \mathrm{Foxp}^{-}$to $\mathrm{CD} 4^{+}$Foxp 3 , thereby expanding the range of Treg specificities to exogenous antigens [80]. Conversely, pTreg can revert to effector T cells, losing expression of Foxp3 under certain situations and thus pTreg are not irreversibly programmed [81]. 
TGF- $\beta$ and its receptor signal pathway is essential for the generation of $\mathrm{pTreg}$ as diminishing TGF- $\beta$ receptor signaling blocks the induction of Foxp3 expression and the resulting operational suppressive capability [82] [83] [84]. TGF- $\beta$ downregulates the expression of growth factor independent 1 , a transcriptional repressor that inhibits Treg differentiation [85]. TGF- $\beta$ also antagonizes DNA methyltransferase 1 (Dnmt1), which inhibits the expression of Foxp3 [86]. CNS-1, a non-coding region of Foxp3 locus are a crucial regulatory element in the generation of $\mathrm{p}$ Treg [87]. CNS1, which possesses a TGF $\beta$-NFAT response element are involved in pTreg differentiation in GALT [88].

IL-2 play a vital part in the differentiation of Foxp $3^{+}$pTreg as TGF- $\beta$ fails to induce Foxp $3^{+}$pTreg from naïve $\mathrm{CD} 4^{+} \mathrm{CD} 25^{-}$cells in mice deficient in IL-2 [89] [90] [91]. Downstream STAT5-dependent IL2 signaling is also essential for the differentiation of pTreg [92] [93] [94].

Retinoic acid (RA), a vitamin A metabolite plays a significant role in enhancing the generation of Foxp3 Treg cells in the GALT [95]. However, the molecular mechanism by which RA promotes TGF $\beta$-mediated Foxp3 induction has controversies. RA has been demonstrated to enhance Foxp3 expression by promoting the expression of Smad 3, thereby amplifying Foxp3 transcription [96] [97]. However, another study has suggested that even though RA appears to increase Smad 3, it augments Treg cell translation independently of Smad 3 [98].

Smad 2 and Smad 3 participate in the pTreg differentiation process and they are activated through TGF- $\beta$ signaling pathways by inducing Foxp3 [99] [100]. Smad 2 and 3 induces the expression of TGF- $\beta$ induced transcription factor, TGF- $\beta$-inducible early gene 1 product (TIEG1), which induces Foxp 3 and its transcription [96]. In addition, Smad 2 and Smad 3 are also appeared to stimulate differentiation of pTreg though Foxp3-independent pathway [101].

Besides $p$ Treg, there are other types of Treg including $\operatorname{Tr} 1$ cells ( $\mathrm{T}$ regulatory type 1) and Th3 Treg [114] [115]. Tr1 population are disturbed in individuals with prolonged inflammatory conditions like colitis, arthritis and asthma. IL-10 is the major cytokine involved in $\operatorname{Tr} 1$ cells differentiation pathway [102]. Once mature, they exert their suppressive activity through the production of large amounts of IL-10 [46]. Usually $\operatorname{Tr} 1$ cells do not express Foxp3 constitutively, however, when activated, they can induce Foxp3 expression [116]. There is accumulating evidence that $\operatorname{Tr} 1$ cells do not require Foxp3 expression in order to exert their suppressive potency, as $\operatorname{Tr} 1$ cells suppress conventional $\mathrm{T}$ cells independent of Foxp3 expression [117] [118]. In addition, it is revealed that $\operatorname{Tr} 1$ cells may be differentiated from naive T cells in patients with IPEX disease [119]. An essential growth factor for the development of Tr1 is IL-15, which can mediate $\operatorname{Tr} 1$ cell differentiation without TCR triggering [103] [104].

IL10 and IL27 are the major cytokines involved in the differentiation of $\operatorname{Tr} 1$ cells [105] [106]. IL27 signaling results activation of transcription factors including c-Maf, IL21, and the costimulatory receptor ICOS [105]. c-Maf is the key 
factor, which activates IL21 production. IL21, an autocrine growth factor drives the proliferation of $\operatorname{Tr} 1$ cells [107]. ICOS stimulates the IL27-induced differentiation of Tr1. Currently, the aryl hydrocarbon receptor (AhR), also induced by IL27, was shown to be involved in the differentiation of $\operatorname{Tr} 1$ [108]. c-Maf and AhR perform synergistically to facilitate proliferation of $\operatorname{Tr} 1$ [109]. In the case of Tr1, as IL-10 can also be produced by both Th1 (IFN $\left.\gamma^{+}\right)$and Th2 (IL- $\left.4^{+}\right)$effectors, definition of this subset is relatively fluid [120].

Th3 cells were first recognized due to their role in immune tolerance after oral ingestion of antigens [110]. Th3 mediate their suppressive activity by the production of TGF- $\beta$. Mice deficient in Th3 often develop spontaneous autoimmunity and Th3 exhibit a mutual relationship with Th17 cells [111] [112]. Th17 being proinflammatory are essential in autoimmune related disorders [121] [122]. No specific surface marker has been identified so far for Th3 cells, though Th3 is induced by Foxp3 expression.

Apart from Foxp3-expressing Treg there are other functional regulatory cells, which are involved in IL-35 production (Tr35) [113]. While Treg are commonly found to be $\mathrm{CD} 4^{+}, \mathrm{CD} 8^{+} \mathrm{T}$ cells might express Foxp3 and produce the same suppressive cytokines [123].

\subsubsection{Markers to Distinguish tTreg from pTreg}

The tTreg vary in functionality from pTreg, however, the major problem in exploring the relative function of these two subsets is the lack of markers to distinguish the two populations.

Helios, a T cell restricted member of Ikaros family transcription factor has been demonstrated to be useful for distinguishing these two Treg populations [124] [125]. Helios is preferentially expressed by tTreg, whereas Treg generated in vitro and in vivo are negative for Helios expression [124]. However, others have described that pTreg can express Helios as when $\mathrm{T}$ cells were stimulated with irradiated splenocytes, more than half of the pTreg expressed Helios [126]. In addition, Helios is also expressed on Th2 and T follicular helper cells and is related to the differentiation of these cells [127]. It is reported that activated Foxp3 $\mathrm{T}$ cells also express helios and in fact a marker for Treg activation [128]. Also expression of Helios has been shown to be associated with $\mathrm{T}$ cell tolerance in both thymus and periphery [129]. Thus Helios does not appear to be a marker to distinguish $\mathrm{pTreg}$ from tTreg.

Neuropilin-1 (Nrp1) expression, a neuronal receptor of the class 3 semaphorin subfamily and a co-receptor for vascular endothelial growth factor A, offers another biological marker to distinguish tTreg from pTreg [130] [131]. In contrast to low levels of Nrp1 expressed on pTreg, majority of tTreg express Nrp1 [130]. However, others have demonstrated that Treg generated extrathymically in the central nervous system during a spontaneous model of EAE were Nrp+ [125]. In addition, Nrp1 is not a marker for human Treg [132]. Thus Nrp1 appeared to be an imperfect marker to distinguish pTreg from tTreg. 
Lap, a component of latent TGF $\beta$ and Garp (Lrrc32), a membrane anchoring molecule that binds to latent TGF $\beta$, were found to be expressed on the surface of Treg [133]. While Lap and Garp expression selectively identifies tTreg that represent a stable subset with highly potent suppressive ability, pTreg fail to express surface Lap or Garp [134]. Recently transcription factor Krüppel-like factor 2 (KLF2) has been demonstrated for the generation of pTreg [135]. KLF2 is not required for the generation of tTreg and is only necessary for pTreg development. In addition, it has been exhibited that drugs that block KLF2 proteolysis during $\mathrm{T}$ cell activation augment $\mathrm{p}$ Treg development.

\subsection{Mechanism of Suppression of Treg}

To date a number of mechanisms have been associated with the suppressive action of Treg suppression. Treg execute their suppressive function rapidly when they are activated via the $\mathrm{T}$ cell receptor, either specifically by its natural class II ligand, or by foreign antigens that are cross-reactive to self-antigen receptors in the periphery [136].

IL-10 and TGF- $\beta$ are potent immune-suppressants that facilitate Treg to inhibit Th1 inflammatory responses. IL-10 has been illustrated as the key components in the suppressive function of Treg (Figure 2) [137]. Secretion of IL-10 by Treg cells has been shown to be essential for the prevention of experimental

\section{A. Inhibitory cytokines}

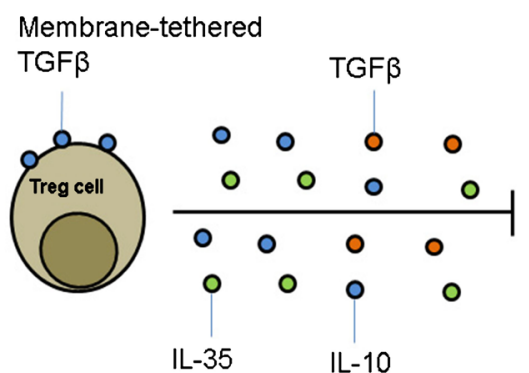

B. Modulation of DC functions

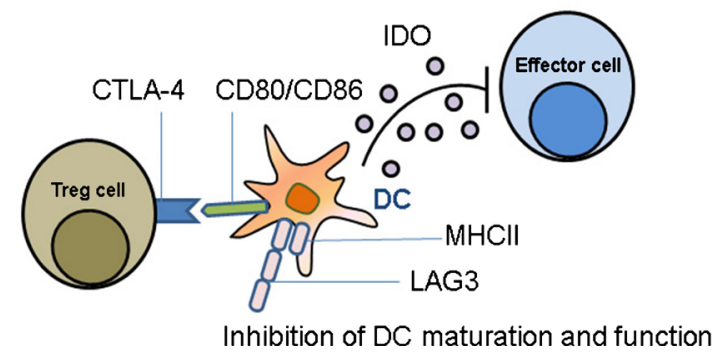

C. Cytolysis

Granzyme A or granzyme B
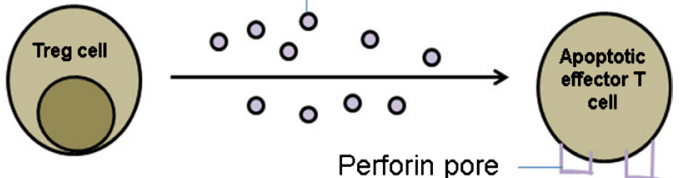

Figure 2. Potential mechanisms used by Treg cells. Illustration of various Treg cell suppressive mechanisms based on three basic modes of action: A. Inhibitory cytokines consists of TGF $\beta$, IL-35 and IL-10. B. Modulation of DC includes mechanisms that influences DC maturation and function such as LAG3, MHC-II-mediated suppression of DC maturation, and CTLA4-CD80/CD86-mediated induction of IDO, which is an immunosuppressive molecule made by DCs. C. Cytolysis consists of granzyme A and granzyme B dependent and perforin pore dependent killing mechanisms. The concept of the figure emerged from [168]. 
autoimmune encephalomyelitis [138], colitis [139] [140], airway allergic response in lung [141] and skin hypersensitivity [142].

TGF- $\beta$, is a well-recognized inhibitory cytokine, however, the function of TGF- $\beta$ in Treg mediated suppression has some controversies (Figure 2). Mice with a T-cell specific deletion of $\operatorname{tg} f b 1$ gene developed lethal immunopathology and could not inhibit inflammatory bowel disease in a transfer model [143]. TGF- $\beta$ was found to be the major mechanism of suppression of prostate tumour infiltrating CD8 cells [144].

Membrane-tethered TGF- $\beta$ expressed by Treg cells has also been demonstrated by Treg cell mediated suppression [145] [146]. However, another study has demonstrated conflicting findings that membrane-tethered TGF- $\beta$ is dispensable for Treg function [147].

Another cytokine, IL-35, a member of IL-12 family has also been attributed to the in vitro and in vivo suppressive potency of Treg [148]. IL-35 consists of Epstein-Barr virus induced gene 3 (Ebi3) and IL-12a/p35, both are highly expressed by Treg but not by naïve or activated T cells [113] [149]. Treg cells from Ebi3 and IL-12a-deficient mice have a reduced suppressive capability in vitro and fail to cure inflammatory bowel disease in vivo [148].

There is evidence that Treg can indirectly suppress other cells through modulation of DC function (Figure 2). Treg cells suppress the capacity of DCs to activate $\mathrm{T}$ cells by down-regulating costimulatory molecules CD80 and CD86 [150] [151]. A handful of molecules expressed at high levels in Treg have been identified which facilitate the blockade of DC maturation and DC mediated activation of effector cells. Among them the most well-known is CTLA4. CTLA4 a member of CD28/B7 family and CTLA4 mediated immunosuppression has been demonstrated in several settings including autoimmune diseases and different tumour types [152] [153]. Mice with a Treg cell specific deletion of CTLA-4 develop systemic autoimmunity and CTLA4-deficient mice inhibit upregulation of CD80 and CD86 even in the presence of strong DC maturation stimuli [152] [154] [155] [156]. Moreover, anti-CTLA4 inhibits the ability of Treg cells to suppress colitis [154].

Treg cells can induce the expression of indoleamine 2, 3-dioxygenase (IDO) in DCs in a CTLA4-dependent manner [157]. IDO is a potent immunosuppressive enzyme which induces catabolism of tryptophan in to pro-apoptotic metabolites, resulting in the suppression of effector cells [158]. Ligation of CTLA-4 to CD80 and CD86 induce DCs by activating transcription factor Foxo3, which downregulate production of IL-6 and TNFa by DCs [159].

Other molecules expressed by Treg that can affect the function of DCs are: Lymphocyte activation gene-3 (LAG-3) [160] [161], immunoreceptor tyrosine-based activation motif (ITAM) [162] and Fibrinogen-like protein 2 (FGL2) [163]. Treg cells from LAG-3 deficient mice had a decreased suppressive activity and anti-LAG-3 blocked suppressive activity of Treg cells both in vitro and in vivo [160] [164]. 
Treg cells can suppress DC maturation by inhibiting down-regulation of MARCH1 and upregulation of CD83 [165]. MARCH1, a membrane bound E3 ubiquitin ligase, was found to degrade CD86 and MHC-II on DC by directing them to the late endosomal or lysosomal compartment [166]. CD83 is accompanied by DC maturation and it inhibits the action of MARCH1 [167]. Treg use IL-10 to influence MARCH1-CD83 pathway.

There is growing evidence that Programmed death 1 (PD-1) pathway plays a role in Treg mediated suppression [169] [170]. PD-1 is expressed predominantly on exhausted CD8 cells and PD-L1, the ligand for PD-1is expressed on Treg and tumour cells [171]. In a BL/6 model, Treg from tumour draining lymph node suppress via $\mathrm{PD}-1 / \mathrm{PD}-\mathrm{L} 1$ pathway. In samples of $\mathrm{T}$ cells taken from melanoma patients, $\mathrm{PD}-1$ blockade was found to enhance effector $\mathrm{T}$ cell proliferation and inhibit the suppressive function of PD-L1 expressing Treg [172]. Treg have also been shown to mediate their suppressive activity through Fas-FasL interaction resulting in apoptosis of B cells [173].

Treg are able to mediate immune suppression by triggering direct cytolysis of target cells [174] [175] [176]. Granzyme and perforin pathway are two suggested mechanisms for Treg mediated immune suppression (Figure 2). Treg cells from mice deficient in granzyme B had a reduced suppressive activity [177]. Also granzyme B deficient mice were able to clear tumour more effectively than wild type mice since Treg cells inhibit anti-tumour immunity in a granzyme B and perforin dependent manner [178].

Another mechanism of suppression is the induction of metabolic disruption in target cells. Treg can be multiplied significantly by TCR stimulation in presence of high concentrations of IL-2 [179] [180]. As IL-2 is secreted by Th1 type cells, and elevated level of IL-2 acts as a negative-feedback mechanism thereby halts the effector $\mathrm{T}$ cell activity by the expanding Treg [181].

Treg has been found to exert metabolic disruption in target cells by their expression of ectoenzymes CD39 and CD73. Treg from CD39 deficient mice have reduced suppressive functions both in vitro and in vivo [182]. CD39 and CD73 convert proinflammatory nucleotides to anti-inflammatory adenosine and these ectoenzymes catalyse the generation of perinuclear adenosine from extracellular ATP or ADP [183]. Adenosine generated in this process then suppresses effector $\mathrm{T}$ cells via binding to adenosine $\mathrm{A} 2 \mathrm{~A}$ receptor.

IL-17 and IFN- $\gamma$ has been shown to modulate the suppressive capacity of Treg on Th2 immune responses [184] [185].

IRF4 a transcription factor responsible for the differentiation of Th2 cells has been shown to play a role in the in Treg mediated suppression of Th2 responses. Mice wherein irf 4 is depleted in Treg developed a lymphoproliferative disease that occurs due to a selective dysregulation of Th2 cells [186]. T-bet, a transcription factor is indispensible for Th1 cell differentiation. It has been demonstrated that Treg mediated suppression of Th1 is regulated by Treg expression of T-bet [187]. Treg mediated suppression of Th17 responses is regulated by Treg expres- 
sion of STAT3. Selective ablation of STAT3 in Treg cells results selective uncontrolled Th17 dependent pathology of intestinal mucosa [41]. Other researchers have described a subset of Foxp3+Treg that express the Tfh cell master transcriptional regulator, Bcl-6/Blimp-1 and accumulation at sites of B cell germinal centre responses where they function to control these reactions [188] [189] [190] [191].

\subsection{Depletion of Treg Using Mouse Model}

A number of different methods to deplete Treg depletion have been used to study their function and variable degrees of depletion have been seen. The two commonly used methods are: antibody depletion method and transgenic mouse model depletion. With the recognition of the IL-2 receptor CD25 on Treg, antibodies specific to CD25 have been developed. About 65\% - 70\% of Treg populations are depleted following introduction of anti-CD25 antibody clone i.e., PC-61 [192]. Also, a population of CD25-Foxp $3^{+}$Treg cells cannot be depleted using PC61. Importantly, expression of CD25 is induced on activated conventional CD4 ${ }^{+} \mathrm{T}$ cells [18] [19] [20] [21].

To deal with the issue of in vivo function of Treg in immunopathology, mice with fully depleted Treg have been engineered. These mice permit selective ablation of Foxp $3^{+}$Treg while without impairing $\mathrm{CD} 25^{+}$effector $\mathrm{T}$ cells. The genetic introduction of human diphtheria toxin receptor (DTR) targeted to a specific murine cell type has become a prevailing tool to selectively ablate Treg upon DT injection [193]. Rudensky and colleagues generated a knock-in mice called Foxp $3^{\text {DTR }}$ mice in which human DTR is introduced in to the 3 untranslated region of Foxp3 which allow specific depletion of Treg by injecting DT. This model showed more than $97 \%$ depletion of Foxp $3^{+}$cells after DT administration [194]. However, these mice subjected to DT succumb to catastrophic autoimmune disease within 2 - 3 weeks, as a result of massive expansion of diverse array of immune cells.

Suffner et al generated a novel set of BAC (Bacterial Artificial Chromosome) transgenic mouse, called Foxp3.LuciDTR mouse, in which Treg express luciferase and the human DTR [195]. They developed several founder lines with different degrees of Treg depletion such as Foxp3.LuciDTR-3 and Foxp3.LuciDTR-4 and Foxp3.LuciDTR-5. Mice from lines Foxp3.LuciDTR-3, Foxp3.LuciDTR-4 and Foxp3.LuciDTR-5 exhibited $\sim 75 \%, 90 \%$ and $>95 \%$ depletion of Tregs, respectively, while Foxp3.LuciDTR-5 mice did suffer from wasting disease due to autoimmunity. Lahl and Sparwasser [193] produced another BAC technology based transgenic mouse model known as DEpletion of REGulatory $T$ cell (DEREG) mice, which express a DTR fused with GFP protein under the control of an additional Foxp3 promoter, allowing efficient depletion of Foxp $3^{+}$Treg by DT injection. Depletion in DEREG mice led to ablation of Foxp3 ${ }^{+}$Treg to 95\% - 98\% [196].

\section{Concluding Remarks}

There are complex dynamic suppression processes controlling other cells by 
Treg and that involve various inhibitory cytokines, DC function and cytolysis. These mechanisms are different depending upon Treg cell subtypes and the nature of the pathogens. Also they can act together or independently, according to the requirements of the immune system and homeostasis maintenance, or during the progression of various pathological processes. This gives two layers of reinforcement of Treg function: the suppressive effects of Treg and protective potential of Treg against different pathogens and they also alter the functional Treg pool in response to tissue and inflammatory cues. Together, these data suggest Treg mediated suppression might be a valuable component in different pathogens, which might provide novel therapeutic approaches for vaccination against them. Further investigations are required on Treg in different type of infection models in order to extend the current understanding on the salient features of these cells, their either beneficial or detrimental role during infection and their mechanisms participating to the immunity against various pathogens.

\section{Conflicts of Interest}

No potential conflicts of interest relevant to this article were reported.

\section{References}

[1] Belkaid, Y. (2007) Regulatory T Cells and Infection: A Dangerous Necessity. Nature Reviews Immunology, 7, 875-888. https://doi.org/10.1038/nri2189

[2] Povoleri, G.A., et al. (2013) Thymic versus Induced Regulatory T Cells-Who Regulates the Regulators? Frontiers in Immunology, 4, 169. https://doi.org/10.3389/fimmu.2013.00169

[3] Liston, A. and Gray, D.H. (2014) Homeostatic Control of Regulatory T Cell Diversity. Nature Reviews Immunology, 14, 154-165. https://doi.org/10.1038/nri3605

[4] Maizels, R.M. and Smith, K.A. (2011) Regulatory T Cells in Infection. Advances in Immunology, 112, 73-136. https://doi.org/10.1016/B978-0-12-387827-4.00003-6

[5] Mittrucker, H.W. and Kaufmann, S.H. (2004) Mini-Review: Regulatory T Cells and Infection: Suppression Revisited. European Journal of Immunology, 34, 306-312. https://doi.org/10.1002/eji.200324578

[6] Sakaguchi, S., et al. (2001) Immunologic Tolerance Maintained by CD25+ CD4 ${ }^{+}$ Regulatory T Cells: Their Common Role in Controlling Autoimmunity, Tumor Immunity, and Transplantation Tolerance. Immunological Reviews, 182, 18-32. https://doi.org/10.1034/j.1600-065X.2001.1820102.x

[7] Belkaid, Y. and Rouse, B.T. (2005) Natural Regulatory T Cells in Infectious Disease. Nature Immunology, 6, 353-360. https://doi.org/10.1038/ni1181

[8] Umetsu, D.T. and De Kruyff, R.H. (2006) The Regulation of Allergy and Asthma. Immunological Reviews, 212, 238-255. https://doi.org/10.1111/j.0105-2896.2006.00413.x

[9] Fehervari, Z. and Sakaguchi, S. (2004) $\mathrm{CD}^{+}$Tregs and Immune Control. Journal of Clinical Investigation, 114, 1209-1217. https://doi.org/10.1172/JCI200423395

[10] Baecher-Allan, C., et al. (2003) CD4 ${ }^{+} \mathrm{CD} 25+$ Regulatory Cells from Human Peripheral Blood Express Very High Levels of CD25 ex Vivo. Novartis Foundation Symposium, 252, 67-91, 106-114.

[11] Baecher-Allan, C., et al. (2001) CD4 ${ }^{+} \mathrm{CD} 25$ High Regulatory Cells in Human Pe- 
ripheral Blood. The Journal of Immunology, 167, 1245-1253.

https://doi.org/10.4049/jimmunol.167.3.1245

[12] Itoh, M., et al. (1999) Thymus and Autoimmunity: Production of CD25+CD4 ${ }^{+}$ Naturally Anergic and Suppressive T Cells as a Key Function of the Thymus in Maintaining Immunologic Self-Tolerance. The Journal of Immunology, 162, 5317-5326.

[13] Yi, H., et al. (2006) The Phenotypic Characterization of Naturally Occurring Regulatory CD4 ${ }^{+} \mathrm{CD} 25+$ T Cells. Cellular \& Molecular Immunology, 3, 189-195.

[14] Deaglio, S., et al. (2007) Adenosine Generation Catalyzed by CD39 and CD73 Expressed on Regulatory T Cells Mediates Immune Suppression. The Journal of $E_{X-}$ perimental Medicine, 204, 1257-1265. https://doi.org/10.1084/jem.20062512

[15] Fontenot, J.D. and Rudensky, A.Y. (2004) Molecular Aspects of Regulatory T Cell Development. Seminars in Immunology, 16, 73-80. https://doi.org/10.1016/j.smim.2003.12.002

[16] Ustun, C., Miller, J.S., Munn, D.H., Weisdorf, D.J. and Blazar, B.R. (2011) Regulatory T Cells in Acute Myelogenous Leukemia: Is It Time for Immunomodulation? Blood, 118, 5084-5095. https://doi.org/10.1182/blood-2011-07-365817

[17] Piccirillo, C.A. and Shevach, E.M. (2004) Naturally-Occurring CD4+ CD25+ Immunoregulatory T Cells: Central Players in the Arena of Peripheral Tolerance. Seminars in Immunology, 16, 81-88. https://doi.org/10.1016/j.smim.2003.12.003

[18] Leithauser, F., Meinhardt-Krajina, T., Fink, K., Wotschke, B., Möller, P. and Reimann, J. (2006) Foxp3-Expressing CD103+ Regulatory T Cells Accumulate in Dendritic Cell Aggregates of the Colonic Mucosa in Murine Transfer Colitis. American Journal of Pathology, 168, 1898-1909. https://doi.org/10.2353/ajpath.2006.050228

[19] Needham, D.J., Lee, J.X. and Beilharz, M.W. (2006) Intra-Tumoural Regulatory T Cells: A Potential New Target in Cancer Immunotherapy. Biochemical and Biophysical Research Communications, 343, 684-691. https://doi.org/10.1016/j.bbrc.2006.03.018

[20] Sakaguchi, S. (2005) Naturally Arising Foxp3-Expressing CD25+ CD4+ Regulatory T Cells in Immunological Tolerance to Self and Non-Self. Nature Immunology, 6, 345-352. https://doi.org/10.1038/ni1178

[21] Buckner, J.H. (2010) Mechanisms of Impaired Regulation by CD4(+) CD25(+) FOXP3(+) Regulatory T Cells in Human Autoimmune Diseases. Nature Reviews Immunology, 10, 849-859. https://doi.org/10.1038/nri2889

[22] Fontenot, J.D. and Rudensky, A.Y. (2005) A Well Adapted Regulatory Contrivance: Regulatory T Cell Development and the Forkhead Family Transcription Factor Foxp3. Nature Immunology, 6, 331-337. https://doi.org/10.1038/ni1179

[23] Brunkow, M.E., et al. (2001) Disruption of a New Forkhead/Winged-Helix Protein, Scurfin, Results in the Fatal Lymphoproliferative Disorder of the Scurfy Mouse. Nature Genetics, 27, 68-73. https://doi.org/10.1038/83784

[24] Fontenot, J.D., Gavin, M.A. and Rudensky, A.Y. (2003) Foxp3 Programs the Development and Function of CD4+ CD25+ Regulatory T Cells. Nature Immunology, 4, 330-336. https://doi.org/10.1038/ni904

[25] Hori, S., Nomura, T. and Sakaguchi, S. (2003) Control of Regulatory T Cell Development by the Transcription Factor Foxp3. Science, 299, 1057-1061. https://doi.org/10.1126/science.1079490

[26] Fontenot, J.D., Rasmussen, J.P., Williams, L.M., Dooley, J.L., Farr, A.G. and 
Rudensky, A.Y. (2005) Regulatory T Cell Lineage Specification by the Forkhead Transcription Factor Foxp3. Immunity, 22, 329-341. https://doi.org/10.1016/j.immuni.2005.01.016

[27] Bennett, C.L., et al. (2001) The Immune Dysregulation, Polyendocrinopathy, Enteropathy, X-Linked Syndrome (IPEX) Is Caused by Mutations of FOXP3. Nature Genetics, 27, 20-21. https://doi.org/10.1038/83713

[28] Wildin, R.S., et al. (2001) X-Linked Neonatal Diabetes Mellitus, Enteropathy and Endocrinopathy Syndrome Is the Human Equivalent of Mouse Scurfy. Nature Genetics, 27, 18-20. https://doi.org/10.1038/83707

[29] Khattri, R., Cox, T., Yasayko, S.A. and Ramsdell, F. (2003) An Essential Role for Scurfin in CD4+ CD25+ T Regulatory Cells. Nature Immunology, 4, 337-342. https://doi.org/10.1038/ni909

[30] Lu, L.F. and Rudensky, A. (2009) Molecular Orchestration of Differentiation and Function of Regulatory T Cells. Genes \& Development, 23, 1270-1282. https://doi.org/10.1101/gad.1791009

[31] Wan, Y.Y. and Flavell, R.A. (2005) Identifying Foxp3-Expressing Suppressor T Cells with a Bicistronic Reporter. Proceedings of the National Academy of Sciences, 102, 5126-5131. https://doi.org/10.1073/pnas.0501701102

[32] Williams, L.M. and Rudensky, A.Y. (2007) Maintenance of the Foxp3-Dependent Developmental Program in Mature Regulatory T Cells Requires Continued Expression of Foxp3. Nature Immunology, 8, 277-284. https://doi.org/10.1038/ni1437

[33] Rudensky, A.Y. (2011) Regulatory T Cells and Foxp3. Immunological Reviews, 241, 260-268. https://doi.org/10.1111/j.1600-065X.2011.01018.x

[34] Seroogy, C.M. and Gern, J.E. (2005) The Role of T Regulatory Cells in Asthma. Journal of Allergy and Clinical Immunology, 116, 996-999. https://doi.org/10.1016/j.jaci.2005.07.015

[35] Nishikawa, H. and Sakaguchi, S. (2010) Regulatory T Cells in Tumor Immunity. International Journal of Cancer, 127, 759-767. https://doi.org/10.1002/ijc.25429

[36] Arpaia, N., et al. (2013) Metabolites Produced by Commensal Bacteria Promote Peripheral Regulatory T-Cell Generation. Nature, 504, 451-455.

https://doi.org/10.1038/nature12726

[37] Aandahl, E.M., Michaëlsson, J., Moretto, W.J., Hecht, F.M. and Nixon, D.F. (2004) Human CD4+ CD25+ Regulatory T Cells Control T-Cell Responses to Human Immunodeficiency Virus and Cytomegalovirus Antigens. Journal of Virology, 78, 2454-2459. https://doi.org/10.1128/JVI.78.5.2454-2459.2004

[38] McNally, A., Hill, G.R., Sparwasser, T., Thomas, R. and Steptoe, R.J. (2011) CD4+ CD25+ Regulatory T Cells Control CD8+ T-Cell Effector Differentiation by Modulating IL-2 Homeostasis. Proceedings of the National Academy of Sciences, 108, 7529-7534. https://doi.org/10.1073/pnas.1103782108

[39] Terme, M., Chaput, N., Combadiere, B., Ma, A., Ohteki, T. and Zitvogel, L. (2008) Regulatory T Cells Control Dendritic Cell/NK Cell Cross-Talk in Lymph Nodes at the Steady State by Inhibiting CD4+ Self-Reactive T Cells. The Journal of Immunology, 180, 4679-4686. https://doi.org/10.4049/jimmunol.180.7.4679

[40] Iikuni, N., Lourenço, E.V., Hahn, B.H. and La Cava, A. (2009) Cutting Edge: Regulatory T Cells Directly Suppress B Cells in Systemic Lupus Erythematosus. The Journal of Immunology, 183, 1518-1522. https://doi.org/10.4049/jimmunol.0901163

[41] Chaudhry, A., et al. (2009) CD4+ Regulatory T Cells Control TH17 Responses in a Stat3-Dependent Manner. Science, 326, 986-991. 
https://doi.org/10.1126/science.1172702

[42] Ghiringhelli, F., Ménard, C., Martin, F. and Zitvogel, L. (2006) The Role of Regulatory T Cells in the Control of Natural Killer Cells: Relevance during Tumor Progression. Immunological Reviews, 214, 229-238.

https://doi.org/10.1111/j.1600-065X.2006.00445.x

[43] Taams, L.S., et al. (2005) Modulation of Monocyte/Macrophage Function by Human CD4+ CD25+ Regulatory T Cells. Human Immunology, 66, 222-230. https://doi.org/10.1016/j.humimm.2004.12.006

[44] Gri, G., et al. (2008) CD4+ CD25+ Regulatory T Cells Suppress Mast Cell Degranulation and Allergic Responses through OX40-OX40L Interaction. Immunity, 29, 771-781. https://doi.org/10.1016/j.immuni.2008.08.018

[45] Jonuleit, H. and Schmitt, E. (2003) The Regulatory T Cell Family: Distinct Subsets and Their Interrelations. The Journal of Immunology, 171, 6323-6327. https://doi.org/10.4049/jimmunol.171.12.6323

[46] Curotto de Lafaille, M.A. and Lafaille, J.J. (2009) Natural and Adaptive Foxp3+ Regulatory T Cells: More of the Same or a Division of Labor? Immunity, 30, 626-635. https://doi.org/10.1016/j.immuni.2009.05.002

[47] Abbas, A.K., et al. (2013) Regulatory T Cells: Recommendations to Simplify the Nomenclature. Nature Immunology, 14, 307-308. https://doi.org/10.1038/ni.2554

[48] Shevach, E.M. and Thornton, A.M. (2014) tTregs, pTregs, and iTregs: Similarities and Differences. Immunological Reviews, 259, 88-102.

https://doi.org/10.1111/imr.12160

[49] Bayer, A.L., Yu, A., Adeegbe, D. and Malek, T.R. (2005) Essential Role for Interleukin-2 for CD4(+) CD25(+) T Regulatory Cell Development during the Neonatal Period. The Journal of Experimental Medicine, 201, 769-777.

https://doi.org/10.1084/jem.20041179

[50] Lim, H.W., Broxmeyer, H.E. and Kim, C.H. (2006) Regulation of Trafficking Receptor Expression in Human Forkhead Box P3+ Regulatory T Cells. The Journal of Immunology, 177, 840-851. https://doi.org/10.4049/jimmunol.177.2.840

[51] Shevach, E.M. (2009) Mechanisms of Foxp3+ T Regulatory Cell-Mediated Suppression. Immunity, 30, 636-645. https://doi.org/10.1016/j.immuni.2009.04.010

[52] Rubtsov, Y.P., et al. (2010) Stability of the Regulatory T Cell Lineage in Vivo. Science, 329, 1667-1671. https://doi.org/10.1126/science.1191996

[53] Engel, M., Sidwell, T., Vasanthakumar, A., Grigoriadis, G. and Banerjee, A. (2013) Thymic Regulatory T Cell Development: Role of Signalling Pathways and Transcription Factors. Clinical \& Developmental Immunology, 2013, Article ID: 617595. https://doi.org/10.1155/2013/617595

[54] Caramalho, I., Nunes-Cabaço, H., Foxall, R.B. and Sousa, A.E. (2015) Regulatory T-Cell Development in the Human Thymus. Frontiers in Immunology, 6, 395. https://doi.org/10.3389/fimmu.2015.00395

[55] Beissert, S., Schwarz, A. and Schwarz, T. (2006) Regulatory T Cells. Journal of Investigative Dermatology, 126, 15-24. https://doi.org/10.1038/sj.jid.5700004

[56] Jordan, M.S., et al. (2001) Thymic Selection of CD4+ CD25+ Regulatory T Cells Induced by an Agonist Self-Peptide. Nature Immunology, 2, 301-306. https://doi.org/10.1038/86302

[57] Horwitz, D.A., Zheng, S.G. and Gray, J.D. (2008) Natural and TGF-Beta-Induced Foxp3(+) CD4(+) CD25(+) Regulatory T Cells Are Not Mirror Images of Each Other. Trends in Immunology, 29, 429-435. https://doi.org/10.1016/j.it.2008.06.005 
[58] Salomon, B., et al. (2000) B7/CD28 Costimulation Is Essential for the Homeostasis of the CD4+ CD25+ Immunoregulatory T Cells That Control Autoimmune Diabetes. Immunity, 12, 431-440. https://doi.org/10.1016/S1074-7613(00)80195-8

[59] Vang, K.B., et al. (2010) Cutting Edge: CD28 and c-Rel-Dependent Pathways Initiate Regulatory T Cell Development. The Journal of Immunology, 184, 4074-4077. https://doi.org/10.4049/jimmunol.0903933

[60] Lio, C.W., Dodson, L.F., Deppong, C.M., Hsieh, C.S. and Green, J.M. (2010) CD28 Facilitates the Generation of Foxp3(-) Cytokine Responsive Regulatory T Cell Precursors. The Journal of Immunology, 184, 6007-6013. https://doi.org/10.4049/jimmunol.1000019

[61] Malek, T.R., Yu, A., Vincek, V., Scibelli, P. and Kong, L. (2002) CD4 Regulatory T Cells Prevent Lethal Autoimmunity in IL-2Rbeta-Deficient Mice. Implications for the Nonredundant Function of IL-2. Immunity, 17, 167-178.

https://doi.org/10.1016/S1074-7613(02)00367-9

[62] Suzuki, H., et al. (1995) Deregulated T Cell Activation and Autoimmunity in Mice Lacking Interleukin-2 Receptor Beta. Science, 268, 1472-1476.

https://doi.org/10.1126/science.7770771

[63] Zorn, E., et al. (2006) IL-2 Regulates FOXP3 Expression in Human CD4+ CD25+ Regulatory T Cells through a STAT-Dependent Mechanism and Induces the Expansion of These Cells in Vivo. Blood, 108, 1571-1579. https://doi.org/10.1182/blood-2006-02-004747

[64] Wirnsberger, G., Mair, F. and Klein, L. (2009) Regulatory T Cell Differentiation of Thymocytes Does Not Require a Dedicated Antigen-Presenting Cell But Is under T Cell-Intrinsic Developmental Control. Proceedings of the National Academy of Sciences, 106, 10278-10283. https://doi.org/10.1073/pnas.0901877106

[65] Isomura, I., et al. (2009) c-Rel Is Required for the Development of Thymic Foxp3+ CD4 Regulatory T Cells. The Journal of Experimental Medicine, 206, 3001-3014. https://doi.org/10.1084/jem.20091411

[66] Hori, S. (2010) c-Rel: A Pioneer in Directing Regulatory T-Cell Lineage Commitment? European Journal of Immunology, 40, 664-667.

https://doi.org/10.1002/eji.201040372

[67] Marie, J.C., Letterio, J.J., Gavin, M. and Rudensky, A.Y. (2005) TGF-betal Maintains Suppressor Function and Foxp3 Expression in CD4+ CD25+ Regulatory T Cells. The Journal of Experimental Medicine, 201, 1061-1067. https://doi.org/10.1084/jem.20042276

[68] Li, M.O., Sanjabi, S. and Flavell, R.A. (2006) Transforming Growth Factor-Beta Controls Development, Homeostasis, and Tolerance of $\mathrm{T}$ Cells by Regulatory $\mathrm{T}$ Cell-Dependent and -Independent Mechanisms. Immunity, 25, 455-471. https://doi.org/10.1016/j.immuni.2006.07.011

[69] Nazzal, D., Gradolatto, A., Truffault, F., Bismuth, J. and Berrih-Aknin, S. (2014) Human Thymus Medullary Epithelial Cells Promote Regulatory T-Cell Generation by Stimulating Interleukin-2 Production via ICOS Ligand. Cell Death \& Disease, 5 , e1420. https://doi.org/10.1038/cddis.2014.377

[70] Chen, W., et al. (2003) Conversion of Peripheral CD4+ CD25-Naive T Cells to CD4+ CD25+ Regulatory T Cells by TGF-Beta Induction of Transcription Factor Foxp3. The Journal of Experimental Medicine, 198, 1875-1886. https://doi.org/10.1084/jem.20030152

[71] Lan, R.Y., Ansari, A.A., Lian, Z.X. and Gershwin, M.E. (2005) Regulatory T Cells: Development, Function and Role in Autoimmunity. Autoimmunity Reviews, 4, 
351-363. https://doi.org/10.1016/j.autrev.2005.01.007

[72] Zheng, S.G. (2013) Regulatory T Cells vs. Th17: Differentiation of Th17 versus Treg, Are the Mutually Exclusive? American Journal of Clinical and Experimental Immunology, 2, 94-106.

[73] Chai, J.N., Zhou, Y.W. and Hsieh, C.S. (2014) T Cells and Intestinal Commensal Bacteria-Ignorance, Rejection, and Acceptance. FEBS Letters, 588, 4167-4175. https://doi.org/10.1016/j.febslet.2014.06.040

[74] Yuan, X., Cheng, G. and Malek, T.R. (2014) The Importance of Regulatory T-Cell Heterogeneity in Maintaining Self-Tolerance. Immunological Reviews, 259, 103-114. https://doi.org/10.1111/imr.12163

[75] Gobert, M. and Lafaille, J.J. (2012) Maternal-Fetal Immune Tolerance, Block by Block. Cell, 150, 7-9. https://doi.org/10.1016/j.cell.2012.06.020

[76] Fu, S., et al. (2004) TGF-Beta Induces Foxp3+ T-Regulatory Cells from CD4+ CD25-Precursors. American Journal of Transplantation, 4, 1614-1627. https://doi.org/10.1111/j.1600-6143.2004.00566.x

[77] Horwitz, D.A., Zheng, S.G. and Gray, J.D. (2003) The Role of the Combination of IL-2 and TGF-Beta or IL-10 in the Generation and Function of CD4+ CD25+ and $\mathrm{CD}^{+}$Regulatory T Cell Subsets. Journal of Leukocyte Biology, 74, 471-478. https://doi.org/10.1189/jlb.0503228

[78] Yamagiwa, S., Gray, J.D., Hashimoto, S. and Horwitz, D.A. (2001) A Role for TGF-Beta in the Generation and Expansion of CD4+ CD25+ Regulatory T Cells from Human Peripheral Blood. The Journal of Immunology, 166, 7282-7289. https://doi.org/10.4049/jimmunol.166.12.7282

[79] Rudensky, A.Y. and Campbell, D.J. (2006) In Vivo Sites and Cellular Mechanisms of T Reg Cell-Mediated Suppression. The Journal of Experimental Medicine, 203, 489-492. https://doi.org/10.1084/jem.20060214

[80] Bluestone, J.A. and Abbas, A.K. (2003) Natural versus Adaptive Regulatory T Cells. Nature Reviews Immunology, 3, 253-257. https://doi.org/10.1038/nri1032

[81] Whiteside, T.L. (2014) Induced Regulatory T Cells in Inhibitory Microenvironments Created by Cancer. Expert Opinion on Biological Therapy, 14, 1411-1425. https://doi.org/10.1517/14712598.2014.927432

[82] Lu, L., et al. (2010) Synergistic Effect of TGF-Beta Superfamily Members on the Induction of Foxp3+ Treg. European Journal of Immunology, 40, 142-152. https://doi.org/10.1002/eji.200939618

[83] Lu, L., et al. (2010) Role of SMAD and Non-SMAD Signals in the Development of Th17 and Regulatory T Cells. The Journal of Immunology, 184, 4295-4306. https://doi.org/10.4049/jimmunol.0903418

[84] Zhou, X., et al. (2010) Isolation of Purified and Live Foxp3+ Regulatory T Cells Using FACS Sorting on Scatter Plot. Journal of Molecular Cell Biology, 2, 164-169. https://doi.org/10.1093/jmcb/mjq007

[85] Chalmin, F., et al. (2012) Stat3 and Gfi-1 Transcription Factors Control Th17 Cell Immunosuppressive Activity via the Regulation of Ectonucleotidase Expression. Immunity, 36, 362-373. https://doi.org/10.1016/j.immuni.2011.12.019

[86] Li, C., Ebert, P.J. and Li, Q.J. (2013) T Cell Receptor (TCR) and Transforming Growth Factor Beta (TGF-Beta) Signaling Converge on DNA (Cytosine-5)-Methyltransferase to Control Forkhead Box Protein 3 (Foxp3) Locus Methylation and Inducible Regulatory T Cell Differentiation. The Journal of Biological Chemistry, 288, 19127-19139. https://doi.org/10.1074/jbc.M113.453357 
[87] Yadav, M., Stephan, S. and Bluestone, J.A. (2013) Peripherally Induced Tregs-Role in Immune Homeostasis and Autoimmunity. Frontiers in Immunology, 4, 232. https://doi.org/10.3389/fimmu.2013.00232

[88] Zheng, Y., Josefowicz, S., Chaudhry, A., Peng, X.P., Forbush, K. and Rudensky, A.Y. (2010) Role of Conserved Non-Coding DNA Elements in the Foxp3 Gene in Regulatory T-Cell Fate. Nature, 463, 808-812. https://doi.org/10.1038/nature08750

[89] Zheng, S.G., Wang, J., Wang, P., Gray, J.D. and Horwitz, D.A. (2007) IL-2 Is Essential for TGF-Beta to Convert Naive CD4+ CD25-Cells to CD25+ Foxp3+ Regulatory T Cells and for Expansion of These Cells. The Journal of Immunology, 178, 20182027. https://doi.org/10.4049/jimmunol.178.4.2018

[90] Lu, L., et al. (2011) All-Trans Retinoic Acid Promotes TGF-Beta-Induced Tregs via Histone Modification But Not DNA Demethylation on Foxp3 Gene Locus. PLoS ONE, 6, e24590. https://doi.org/10.1371/journal.pone.0024590

[91] Shi, Q., et al. (2011) CD4+ Foxp3+ Regulatory T Cells Induced by TGF-Beta, IL-2 and All-Trans Retinoic Acid Attenuate Obliterative Bronchiolitis in Rat Trachea Transplantation. International Immunopharmacology, 11, 1887-1894. https://doi.org/10.1016/j.intimp.2011.07.020

[92] Laurence, A., et al. (2007) Interleukin-2 Signaling via STAT5 Constrains T Helper 17 Cell Generation. Immunity, 26, 371-381. https://doi.org/10.1016/j.immuni.2007.02.009

[93] Burchill, M.A., Yang, J., Vogtenhuber, C., Blazar, B.R. and Farrar, M.A. (2007) IL-2 Receptor Beta-Dependent STAT5 Activation Is Required for the Development of Foxp3+ Regulatory T Cells. The Journal of Immunology, 178, 280-290. https://doi.org/10.4049/jimmunol.178.1.280

[94] Brandenburg, S., et al. (2008) IL-2 Induces in Vivo Suppression by CD4(+) CD25(+) Foxp3(+) Regulatory T Cells. European Journal of Immunology, 38, 1643-1653. https://doi.org/10.1002/eji.200737791

[95] Hall, J.A., Grainger, J.R., Spencer, S.P. and Belkaid, Y. (2011) The Role of Retinoic Acid in Tolerance and Immunity. Immunity, 35, 13-22.

https://doi.org/10.1016/j.immuni.2011.07.002

[96] Maruyama, T., Konkel, J.E., Zamarron, B.F. and Chen, W. (2011) The Molecular Mechanisms of Foxp3 Gene Regulation. Seminars in Immunology, 23, 418-423. https://doi.org/10.1016/j.smim.2011.06.005

[97] Xiao, S., et al. (2008) Retinoic Acid Increases Foxp3+ Regulatory T Cells and Inhibits Development of Th17 Cells by Enhancing TGF-Beta-Driven Smad3 Signaling and Inhibiting IL-6 and IL-23 Receptor Expression. The Journal of Immunology, 181, 2277-2284. https://doi.org/10.4049/jimmunol.181.4.2277

[98] Nolting, J., et al. (2009) Retinoic Acid Can Enhance Conversion of Naive into Regulatory $\mathrm{T}$ Cells Independently of Secreted Cytokines. The Journal of Experimental Medicine, 206, 2131-2139. https://doi.org/10.1084/jem.20090639

[99] Yoshimura, A. and Muto, G. (2011) TGF-Beta Function in Immune Suppression. Current Topics in Microbiology and Immunology, 350, 127-147. https://doi.org/10.1007/82_2010_87

[100] Takimoto, T., et al. (2010) Smad2 and Smad3 Are Redundantly Essential for the TGF-Beta-Mediated Regulation of Regulatory T Plasticity and Th1 Development. The Journal of Immunology, 185, 842-855. https://doi.org/10.4049/jimmunol.0904100

[101] Luckheeram, R.V., Zhou, R., Verma, A.D. and Xia, B. (2012) CD4(+) T Cells: Differentiation and Functions. Clinical \& Developmental Immunology, 2012, Article 
ID: 925135. https://doi.org/10.1155/2012/925135

[102] Couper, K.N., et al. (2008) IL-10 from CD4CD25Foxp3CD127 Adaptive Regulatory T Cells Modulates Parasite Clearance and Pathology during Malaria Infection. PLOS Pathogens, 4, e1000004. https://doi.org/10.1371/journal.ppat.1000004

[103] Fujio, K., Okamura, T. and Yamamoto, K. (2010) The Family of IL-10-Secreting CD4+ T Cells. Advances in Immunology, 105, 99-130. https://doi.org/10.1016/S0065-2776(10)05004-2

[104] Roncarolo, M.G., et al. (2006) Interleukin-10-Secreting Type 1 Regulatory T Cells in Rodents and Humans. Immunological Reviews, 212, 28-50. https://doi.org/10.1111/j.0105-2896.2006.00420.x

[105] Awasthi, A., et al. (2007) A Dominant Function for Interleukin 27 in Generating Interleukin 10-Producing Anti-Inflammatory T Cells. Nature Immunology, 8, 1380-1389. https://doi.org/10.1038/ni1541

[106] Gregori, S., et al. (2010) Differentiation of Type 1 T Regulatory Cells (Tr1) by Tolerogenic DC-10 Requires the IL-10-Dependent ILT4/HLA-G Pathway. Blood, 116, 935-944. https://doi.org/10.1182/blood-2009-07-234872

[107] Pot, C., et al. (2009) Cutting Edge: IL-27 Induces the Transcription Factor c-Maf, Cytokine IL-21, and the Costimulatory Receptor ICOS That Coordinately Act Together to Promote Differentiation of IL-10-Producing Tr1 Cells. The Journal of Immunology, 183, 797-801. https://doi.org/10.4049/jimmunol.0901233

[108] Quintana, F.J. and Sherr, D.H. (2013) Aryl Hydrocarbon Receptor Control of Adaptive Immunity. Pharmacological Reviews, 65, 1148-1161.

https://doi.org/10.1124/pr.113.007823

[109] Apetoh, L., et al. (2010) The Aryl Hydrocarbon Receptor Interacts with c-Maf to Promote the Differentiation of Type 1 Regulatory T Cells Induced by IL-27. Nature Immunology, 11, 854-861. https://doi.org/10.1038/ni.1912

[110] Walsh, P.T., Taylor, D.K. and Turka, L.A. (2004) Tregs and Transplantation Tolerance. Journal of Clinical Investigation, 114, 1398-1403.

https://doi.org/10.1172/JCI200423238

[111] Korn, T., Bettelli, E., Oukka, M. and Kuchroo, V.K. (2009) IL-17 and Th17 Cells. Annual Review of Immunology, 27, 485-517. https://doi.org/10.1146/annurev.immunol.021908.132710

[112] Nistala, K. and Wedderburn, L.R. (2009) Th17 and Regulatory T Cells: Rebalancing Pro- and Anti-Inflammatory Forces in Autoimmune Arthritis. Rheumatology ( $\mathrm{OX}^{-}$ ford), 48, 602-606. https://doi.org/10.1093/rheumatology/kep028

[113] Collison, L.W., et al. (2010) IL-35-Mediated Induction of a Potent Regulatory T Cell Population. Nature Immunology, 11, 1093-1101. https://doi.org/10.1038/ni.1952

[114] Roncarolo, M.G., Bacchetta, R., Bordignon, C., Narula, S. and Levings, M.K. (2001) Type 1 T Regulatory Cells. Immunological Reviews, 182, 68-79. https://doi.org/10.1034/j.1600-065X.2001.1820105.x

[115] Weiner, H.L. (2001) Induction and Mechanism of Action of Transforming Growth Factor-Beta-Secreting Th3 Regulatory Cells. Immunological Reviews, 182, 207-214. https://doi.org/10.1034/j.1600-065X.2001.1820117.x

[116] Vieira, P.L., et al. (2004) IL-10-Secreting Regulatory T Cells Do Not Express Foxp3 But Have Comparable Regulatory Function to Naturally Occurring CD4+ CD25+ Regulatory T Cells. The Journal of Immunology, 172, 5986-5993. https://doi.org/10.4049/jimmunol.172.10.5986

[117] Passerini, L., et al. (2011) Functional Type 1 Regulatory T Cells Develop Regardless 
of FOXP3 Mutations in Patients with IPEX Syndrome. European Journal of Immunology, 41, 1120-1131. https://doi.org/10.1002/eji.201040909

[118] Levings, M.K. and Roncarolo, M.G. (2005) Phenotypic and Functional Differences between Human CD4+ CD25+ and Type 1 Regulatory T Cells. Current Topics in Microbiology and Immunology, 293, 303-326.

https://doi.org/10.1007/3-540-27702-1_14

[119] Gol-Ara, M., Jadidi-Niaragh, F., Sadria, R., Azizi, G. and Mirshafiey, A. (2012) The Role of Different Subsets of Regulatory T Cells in Immunopathogenesis of Rheumatoid Arthritis. Arthritis, 2012, Article ID: 805875. https://doi.org/10.1155/2012/805875

[120] Jankovic, D., et al. (2007) Conventional T-bet(+)Foxp3(-) Th1 Cells Are the Major Source of Host-Protective Regulatory IL-10 during Intracellular Protozoan Infection. The Journal of Experimental Medicine, 204, 273-283. https://doi.org/10.1084/jem.20062175

[121] Peterson, R.A. (2012) Regulatory T-Cells: Diverse Phenotypes Integral to Immune Homeostasis and Suppression. Toxicologic Pathology, 40, 186-204. https://doi.org/10.1177/0192623311430693

[122] Crome, S.Q., Wang, A.Y. and Levings, M.K. (2010) Translational Mini-Review Series on Th17 Cells: Function and Regulation of Human T Helper 17 Cells in Health and Disease. Clinical \& Experimental Immunology, 159, 109-119.

https://doi.org/10.1111/j.1365-2249.2009.04037.x

[123] Nakagawa, T., et al. (2010) IL-6 Positively Regulates Foxp3+ CD8+ T Cells in Vivo. International Immunology, 22, 129-139. https://doi.org/10.1093/intimm/dxp119

[124] Thornton, A.M., et al. (2010) Expression of Helios, an Ikaros Transcription Factor Family Member, Differentiates Thymic-Derived from Peripherally Induced Foxp3+ T Regulatory Cells. The Journal of Immunology, 184, 3433-3441. https://doi.org/10.4049/jimmunol.0904028

[125] Lin, X., et al. (2013) Advances in Distinguishing Natural from Induced Foxp3(+) Regulatory T Cells. International Journal of Clinical and Experimental Pathology, 6, 116-123.

[126] Akimova, T., Beier, U.H., Wang, L., Levine, M.H. and Hancock, W.W. (2011) Helios Expression Is a Marker of T Cell Activation and Proliferation. PLoS ONE, 6, e24226. https://doi.org/10.1371/journal.pone.0024226

[127] Serre, K., et al. (2011) Helios Is Associated with CD4 T Cells Differentiating to T Helper 2 and Follicular Helper T Cells in Vivo Independently of Foxp3 Expression. PLoS ONE, 6, e20731. https://doi.org/10.1371/journal.pone.0020731

[128] Gottschalk, R.A., Corse, E. and Allison, J.P. (2012) Expression of Helios in Peripherally Induced Foxp3+ Regulatory T Cells. The Journal of Immunology, 188, 976-980. https://doi.org/10.4049/jimmunol.1102964

[129] Ross, E.M., et al. (2014) Helios Defines T Cells Being Driven to Tolerance in the Periphery and Thymus. European Journal of Immunology, 44, 2048-2058. https://doi.org/10.1002/eji.201343999

[130] Yadav, M., et al. (2012) Neuropilin-1 Distinguishes Natural and Inducible Regulatory T Cells among Regulatory T Cell Subsets in Vivo. The Journal of Experimental Medicine, 209, 1713-1722. https://doi.org/10.1084/jem.20120822

[131] Hansen, W., et al. (2012) Neuropilin 1 Deficiency on CD4+ Foxp3+ Regulatory T Cells Impairs Mouse Melanoma Growth. The Journal of Experimental Medicine, 209, 2001-2016. https://doi.org/10.1084/jem.20111497

[132] Milpied, P., et al. (2009) Neuropilin-1 Is Not a Marker of Human Foxp3+ Treg. 
European Journal of Immunology, 39, 1466-1471. https://doi.org/10.1002/eji.200839040

[133] Dhamne, C., Chung, Y., Alousi, A.M., Cooper, L.J.N. and Tran, D.Q. (2013) Peripheral and Thymic Foxp3(+) Regulatory T Cells in Search of Origin, Distinction, and Function. Frontiers in Immunology, 4, 253.

https://doi.org/10.3389/fimmu.2013.00253

[134] Tran, D.Q., et al. (2009) Selective Expression of Latency-Associated Peptide (LAP) and IL-1 Receptor Type I/II (CD121a/CD121b) on Activated Human FOXP3+ Regulatory T Cells Allows for Their Purification from Expansion Cultures. Blood, 113, 5125-5133. https://doi.org/10.1182/blood-2009-01-199950

[135] Pabbisetty, S.K., et al. (2014) KLF2 Is a Rate-Limiting Transcription Factor That Can Be Targeted to Enhance Regulatory T-Cell Production. Proceedings of the National Academy of Sciences, 111, 9579-9584.

https://doi.org/10.1073/pnas.1323493111

[136] Suffia, I.J., Reckling, S.K., Piccirillo, C.A., Goldszmid, R.S. and Belkaid, Y. (2006) Infected Site-Restricted Foxp3+ Natural Regulatory T Cells Are Specific for Microbial Antigens. The Journal of Experimental Medicine, 203, 777-788.

https://doi.org/10.1084/jem.20052056

[137] Bettini, M. and Vignali, D.A. (2009) Regulatory T Cells and Inhibitory Cytokines in Autoimmunity. Current Opinion in Immunology, 21, 612-618. https://doi.org/10.1016/j.coi.2009.09.011

[138] McGeachy, M.J., Stephens, L.A. and Anderton, S.M. (2005) Natural Recovery and Protection from Autoimmune Encephalomyelitis: Contribution of CD4+ CD25+ Regulatory Cells within the Central Nervous System. The Journal of Immunology, 175, 3025-3032. https://doi.org/10.4049/jimmunol.175.5.3025

[139] Asseman, C., Mauze, S., Leach, M.W., Coffman, R.L. and Powrie, F. (1999) An Essential Role for Interleukin 10 in the Function of Regulatory T Cells That Inhibit Intestinal Inflammation. The Journal of Experimental Medicine, 190, 995-1004. https://doi.org/10.1084/jem.190.7.995

[140] Annacker, O., Asseman, C., Read, S. and Powrie, F. (2003) Interleukin-10 in the Regulation of T Cell-Induced Colitis. Journal of Autoimmunity, 20, 277-279. https://doi.org/10.1016/S0896-8411(03)00045-3

[141] Joetham, A., et al. (2007) Naturally Occurring Lung CD4(+)CD25(+) T Cell Regulation of Airway Allergic Responses Depends on IL-10 Induction of TGF-Beta. The Journal of Immunology, 178, 1433-1442. https://doi.org/10.4049/jimmunol.178.3.1433

[142] Rubtsov, Y.P., et al. (2008) Regulatory T Cell-Derived Interleukin-10 Limits Inflammation at Environmental Interfaces. Immunity, 28, 546-558. https://doi.org/10.1016/j.immuni.2008.02.017

[143] Li, M.O., Wan, Y.Y. and Flavell, R.A. (2007) T Cell-Produced Transforming Growth Factor-Beta1 Controls T Cell Tolerance and Regulates Th1- and Th17-Cell Differentiation. Immunity, 26, 579-591. https://doi.org/10.1016/j.immuni.2007.03.014

[144] Zhang, Q., et al. (2006) Blockade of Transforming Growth Factor-Beta Signaling in Tumor-Reactive CD8(+) T Cells Activates the Antitumor Immune Response Cycle. Molecular Cancer Therapeutics, 5, 1733-1743. https://doi.org/10.1158/1535-7163.MCT-06-0109

[145] Shevach, E.M., Tran, D.Q., Davidson, T.S. and Andersson, J. (2008) The Critical Contribution of TGF-Beta to the Induction of Foxp3 Expression and Regulatory $\mathrm{T}$ Cell Function. European Journal of Immunology, 38, 915-917. 
https://doi.org/10.1002/eji.200738111

[146] Andersson, J., et al. (2008) CD4+ FoxP3+ Regulatory T Cells Confer Infectious Tolerance in a TGF-Beta-Dependent Manner. The Journal of Experimental Medicine, 205, 1975-1981. https://doi.org/10.1084/jem.20080308

[147] Piccirillo, C.A., et al. (2002) CD4(+)CD25(+) Regulatory T Cells Can Mediate Suppressor Function in the Absence of Transforming Growth Factor Beta1 Production and Responsiveness. The Journal of Experimental Medicine, 196, 237-246. https://doi.org/10.1084/jem.20020590

[148] Collison, L.W., et al. (2007) The Inhibitory Cytokine IL-35 Contributes to Regulatory T-Cell Function. Nature, 450, 566-569. https://doi.org/10.1038/nature06306

[149] Chaturvedi, V., Collison, L.W., Guy, C.S., Workman, C.J. and Vignali, D.A. (2011) Cutting Edge: Human Regulatory T Cells Require IL-35 to Mediate Suppression and Infectious Tolerance. The Journal of Immunology, 186, 6661-6666. https://doi.org/10.4049/jimmunol.1100315

[150] Veldhoen, M., et al. (2006) Modulation of Dendritic Cell Function by Naive and Regulatory CD4+ T Cells. The Journal of Immunology, 176, 6202-6210. https://doi.org/10.4049/jimmunol.176.10.6202

[151] Houot, R., Perrot, I., Garcia, E., Durand, I. and Lebecque, S. (2006) Human CD4+ CD25 High Regulatory T Cells Modulate Myeloid But Not Plasmacytoid Dendritic Cells Activation. The Journal of Immunology, 176, 5293-5298. https://doi.org/10.4049/jimmunol.176.9.5293

[152] Wing, K., et al. (2008) CTLA-4 Control over Foxp3+ Regulatory T Cell Function. Science, 322, 271-275. https://doi.org/10.1126/science.1160062

[153] Oderup, C., Cederbom, L., Makowska, A., Cilio, C.M. and Ivars, F. (2006) Cytotoxic T Lymphocyte Antigen-4-Dependent Down-Modulation of Costimulatory Molecules on Dendritic Cells in CD4+ CD25+ Regulatory T-Cell-Mediated Suppression. Immunology, 118, 240-249. https://doi.org/10.1111/j.1365-2567.2006.02362.x

[154] Read, S., et al. (2006) Blockade of CTLA-4 on CD4+ CD25+ Regulatory T Cells Abrogates Their Function in Vivo. The Journal of Immunology, 177, 4376-4383. https://doi.org/10.4049/jimmunol.177.7.4376

[155] Takahashi, T., et al. (2000) Immunologic Self-Tolerance Maintained by CD25(+) CD4(+) Regulatory T Cells Constitutively Expressing Cytotoxic T LymphocyteAssociated Antigen 4. The Journal of Experimental Medicine, 192, 303-310. https://doi.org/10.1084/jem.192.2.303

[156] Friedline, R.H., et al. (2009) CD4+ Regulatory T Cells Require CTLA-4 for the Maintenance of Systemic Tolerance. The Journal of Experimental Medicine, 206, 421-434. https://doi.org/10.1084/jem.20081811

[157] Puccetti, P. and Grohmann, U. (2007) IDO and Regulatory T Cells: A Role for Reverse Signalling and Non-Canonical NF-kappaB Activation. Nature Reviews Immunology, 7, 817-823. https://doi.org/10.1038/nri2163

[158] Mbongue, J.C., et al. (2015) The Role of Indoleamine 2, 3-Dioxygenase in Immune Suppression and Autoimmunity. Vaccines (Basel), 3, 703-729. https://doi.org/10.3390/vaccines3030703

[159] Dejean, A.S., Hedrick, S.M. and Kerdiles, Y.M. (2011) Highly Specialized Role of Forkhead Box O Transcription Factors in the Immune System. Antioxid Redox Signal, 14, 663-674. https://doi.org/10.1089/ars.2010.3414

[160] Liang, B., et al. (2008) Regulatory T Cells Inhibit Dendritic Cells by Lymphocyte Activation Gene-3 Engagement of MHC Class II. The Journal of Immunology, 180, 5916-5926. https://doi.org/10.4049/jimmunol.180.9.5916 
[161] Goldberg, M.V. and Drake, C.G. (2011) LAG-3 in Cancer Immunotherapy. Current Topics in Microbiology and Immunology, 344, 269-278. https://doi.org/10.1007/82_2010_114

[162] Holst, J., et al. (2008) Scalable Signaling Mediated by T Cell Antigen Receptor-CD3 ITAMs Ensures Effective Negative Selection and Prevents Autoimmunity. Nature Immunology, 9, 658-666. https://doi.org/10.1038/ni.1611

[163] Shalev, I., et al. (2008) Targeted Deletion of fgl2 Leads to Impaired Regulatory T Cell Activity and Development of Autoimmune Glomerulonephritis. The Journal of Immunology, 180, 249-260. https://doi.org/10.4049/jimmunol.180.1.249

[164] Huang, C.T., et al. (2004) Role of LAG-3 in Regulatory T Cells. Immunity, 21, 503-513. https://doi.org/10.1016/j.immuni.2004.08.010

[165] Chattopadhyay, G. and Shevach, E.M. (2013) Antigen-Specific Induced T Regulatory Cells Impair Dendritic Cell Function via an IL-10/MARCH1-Dependent Mechanism. The Journal of Immunology, 191, 5875-5884. https://doi.org/10.4049/jimmunol.1301693

[166] Bartee, E., Mansouri, M., Hovey Nerenberg, B.T., Gouveia, K. and Früh, K. (2004) Down-Regulation of Major Histocompatibility Complex Class I by Human Ubiquitin Ligases Related to Viral Immune Evasion Proteins. Journal of Virology, 78, 1109-1120. https://doi.org/10.1128/JVI.78.3.1109-1120.2004

[167] Tze, L.E., et al. (2011) CD83 Increases MHC II and CD86 on Dendritic Cells by Opposing IL-10-Driven MARCH1-Mediated Ubiquitination and Degradation. The Journal of Experimental Medicine, 208, 149-165. https://doi.org/10.1084/jem.20092203

[168] Vignali, D.A., Collison, L.W. and Workman, C.J. (2008) How Regulatory T Cells Work. Nature Reviews Immunology, 8, 523-532. https://doi.org/10.1038/nri2343

[169] Woo, S.R., et al. (2012) Immune Inhibitory Molecules LAG-3 and PD-1 Synergistically Regulate T-Cell Function to Promote Tumoral Immune Escape. Cancer Research, 72, 917-927. https://doi.org/10.1158/0008-5472.CAN-11-1620

[170] Nguyen, L.T. and Ohashi, P.S. (2015) Clinical Blockade of PD1 and LAG3-Potential Mechanisms of Action. Nature Reviews Immunology, 15, 45-56.

https://doi.org/10.1038/nri3790

[171] Riella, L.V., Paterson, A.M., Sharpe, A.H. and Chandraker, A. (2012) Role of the PD-1 Pathway in the Immune Response. American Journal of Transplantation, 12, 2575-2587. https://doi.org/10.1111/j.1600-6143.2012.04224.x

[172] Pardoll, D.M. (2012) The Blockade of Immune Checkpoints in Cancer Immunotherapy. Nature Reviews Cancer, 12, 252-264. https://doi.org/10.1038/nrc3239

[173] Janssens, W., et al. (2003) CD4+ CD25+ T Cells Lyse Antigen-Presenting B Cells by Fas-Fas Ligand Interaction in an Epitope-Specific Manner. The Journal of Immunology, 171, 4604-4612. https://doi.org/10.4049/jimmunol.171.9.4604

[174] Grossman, W.J., Verbsky, J.W., Barchet, W., Colonna, M., Atkinson, J.P. and Ley, T.J. (2004) Human T Regulatory Cells Can Use the Perforin Pathway to Cause Autologous Target Cell Death. Immunity, 21, 589-601.

https://doi.org/10.1016/j.immuni.2004.09.002

[175] Grossman, W.J., Verbsky, J.W., Tollefsen, B.L., Kemper, C., Atkinson, J.P. and Ley, T.J. (2004) Differential Expression of Granzymes A and B in Human Cytotoxic Lymphocyte Subsets and T Regulatory Cells. Blood, 104, 2840-2848. https://doi.org/10.1182/blood-2004-03-0859

[176] Gondek, D.C., Lu, L.F., Quezada, S.A., Sakaguchi, S. and Noelle, R.J. (2005) Cutting 
Edge: Contact-Mediated Suppression by CD4+ CD25+ Regulatory Cells Involves a Granzyme B-Dependent, Perforin-Independent Mechanism. The Journal of Immunology, 174, 1783-1786.

[177] Sojka, D.K., Huang, Y.H. and Fowell, D.J. (2008) Mechanisms of Regulatory T-Cell Suppression-A Diverse Arsenal for a Moving Target. Immunology, 124, 13-22. https://doi.org/10.1111/j.1365-2567.2008.02813.x

[178] Cao, X., et al. (2007) Granzyme B and Perforin Are Important for Regulatory T Cell-Mediated Suppression of Tumor Clearance. Immunity, 27, 635-646. https://doi.org/10.1016/j.immuni.2007.08.014

[179] Fontenot, J.D., Rasmussen, J.P., Gavin, M.A. and Rudensky, A.Y. (2005) A Function for Interleukin 2 in Foxp3-Expressing Regulatory T Cells. Nature Immunology, 6, 1142-1151. https://doi.org/10.1038/ni1263

[180] Huibregtse, I.L., van Lent, A.U. and van Deventer, S.J. (2007) Immunopathogenesis of IBD: Insufficient Suppressor Function in the Gut? Gut, 56, 584-592. https://doi.org/10.1136/gut.2006.103523

[181] Sakaguchi, S., Wing, K., Onishi, Y., Prieto-Martin, P. and Yamaguchi, T. (2009) Regulatory T Cells: How Do They Suppress Immune Responses? International Immunology, 21, 1105-1111. https://doi.org/10.1093/intimm/dxp095

[182] Schmidt, A., Oberle, N. and Krammer, P.H. (2012) Molecular Mechanisms of Treg-Mediated T Cell Suppression. Frontiers in Immunology, 3, 51. https://doi.org/10.3389/fimmu.2012.00051

[183] Longhi, M.S., Robson, S.C., Bernstein, S.H., Serra, S. and Deaglio, S. (2013) Biological Functions of Ecto-Enzymes in Regulating Extracellular Adenosine Levels in Neoplastic and Inflammatory Disease States. Journal of Molecular Medicine, 91, 165-172. https://doi.org/10.1007/s00109-012-0991-z

[184] Ayyoub, M., et al. (2009) Human Memory FOXP3+ Tregs Secrete IL-17 ex Vivo and Constitutively Express the $\mathrm{T}(\mathrm{H}) 17$ Lineage-Specific Transcription Factor RORgamma t. Proceedings of the National Academy of Sciences, 106, 8635-8640. https://doi.org/10.1073/pnas.0900621106

[185] Beriou, G., et al. (2009) IL-17-Producing Human Peripheral Regulatory T Cells Retain Suppressive Function. Blood, 113, 4240-4249. https://doi.org/10.1182/blood-2008-10-183251

[186] Zheng, Y., et al. (2009) Regulatory T-Cell Suppressor Program Co-Opts Transcription Factor IRF4 to Control T(H)2 Responses. Nature, 458, 351-356. https://doi.org/10.1038/nature07674

[187] Koch, M.A., Thomas, K.R., Perdue, N.R., Smigiel, K.S., Srivastava, S. and Campbell, D.J. (2012) T-bet(+) Treg Cells Undergo Abortive Th1 Cell Differentiation Due to Impaired Expression of IL-12 Receptor beta2. Immunity, 37, 501-510. https://doi.org/10.1016/j.immuni.2012.05.031

[188] Linterman, M.A., Liston, A. and Vinuesa, C.G. (2012) T-Follicular Helper Cell Differentiation and the Co-Option of This Pathway by Non-Helper Cells. Immunological Reviews, 247, 143-159. https://doi.org/10.1111/j.1600-065X.2012.01121.x

[189] Kroenke, M.A., et al. (2012) Bcl6 and Maf Cooperate to Instruct Human Follicular Helper CD4 T Cell Differentiation. The Journal of Immunology, 188, 3734-3744. https://doi.org/10.4049/jimmunol.1103246

[190] Liu, X., et al. (2012) Bcl6 Expression Specifies the T Follicular Helper Cell Program in Vivo. The Journal of Experimental Medicine, 209, 1841-1852.

https://doi.org/10.1084/jem.20120219

[191] Perreau, M., et al. (2013) Follicular Helper T Cells Serve as the Major CD4 T Cell 
Compartment for HIV-1 Infection, Replication, and Production. The Journal of Experimental Medicine, 210, 143-156. https://doi.org/10.1084/jem.20121932

[192] Matsushita, N., et al. (2008) Comparative Methodologies of Regulatory T Cell Depletion in a Murine Melanoma Model. The Journal of Immunology Methods, 333, 167-179. https://doi.org/10.1016/j.jim.2008.01.012

[193] Lahl, K. and Sparwasser, T. (2011) In Vivo Depletion of FoxP3+ Tregs Using the DEREG Mouse Model. Methods in Molecular Biology, 707, 157-172. https://doi.org/10.1007/978-1-61737-979-6_10

[194] Kim, J.M., Rasmussen, J.P. and Rudensky, A.Y. (2007) Regulatory T Cells Prevent Catastrophic Autoimmunity throughout the Lifespan of Mice. Nature Immunology, 8, 191-197. https://doi.org/10.1038/ni1428

[195] Suffner, J., et al. (2010) Dendritic Cells Support Homeostatic Expansion of Foxp3+ Regulatory $\mathrm{T}$ Cells in Foxp3.LuciDTR Mice. The Journal of Immunology, 184, 1810-1820. https://doi.org/10.4049/jimmunol.0902420

[196] Lahl, K., et al. (2007) Selective Depletion of Foxp3+ Regulatory T Cells Induces a Scurfy-Like Disease. The Journal of Experimental Medicine, 204, 57-63.

https://doi.org/10.1084/jem.20061852 


\section{Abbreviations}

CTLA-4, Cytotoxic T lymphocyte antigen 4

DEREG, Depletion of regulatory T cells

DTR, Diphtheria toxin receptor

DT, Diphtheria toxin

EAE, Experimental autoimmune encephalomyelitis

Ebi3, Epstein-Barr virus induced gene 3

Foxp3, Forkhead box P3 protein

Foxo, Forkhead box $\mathrm{O}$ transcription factor

ICOS, Inducible T cell costimulatory

IDO, Indoleamine 2, 3-dioxygenase

IPEX, Immune dysregulation, polyendocrinopathy, enteropathy X-linked

IRF, Interferon regulatory factor

ITAM, Immunoreceptor tyrosine-based activation motif

KLF2, Krüppel-like factor 2

LAG-3, Lymphocyte activation gene 3

LAP, Latency associated peptide

MARCH1, Membrane-associated E3 ubiquitin ligase RING-CH1

mTECs, Medullary thymic epithelial cells

NFAT, Nuclear factor of activated T cells

Nrp1, Neuropilin-1

n'Treg cells, Naturally occurring regulatory $\mathrm{T}$ cells

p'Treg, Peripherally derived Treg cell

PD-1, Programmed death 1

PD-L, Programmed death 1 ligand

RA, Retinoic acid

STAT, Signal transducer and activator of transcription

T-bet, T-box expressed in T cells

TCR, T cell receptor

Tfh cell, $\mathrm{T}$ follicular helper cell

TGF $\beta$, Transforming growth factor $\beta$

TIEG1, TGF- $\beta$-inducible early gene 1 product

TNF, Tumour necrosis factor

TNFRSF18, Tumour necrosis factor receptor superfamily 18

$\operatorname{Tr} 1$, T regulatory type 1

Treg, CD $4^{+}$Foxp3+ Regulatory T cell

tTreg, Thymus derived Treg cell 